Seismic monitoring of natural and manmade events in the territory of Karelia

Nikolay V. Sharov* (Institute of geology Karelian recearch center RAS)

\title{
Сейсмічний моніторинг природних і техногенних подій на
}

територіі Кареліі

М.В. Шаров, (Інститут геологї Карельського наукового иеентру РАН)

\section{PEЗЮМЕ}

Слід підкреслити, що саме Карелія, що характеризується незначним за потужністю осадовим чохлом, може стати своєрідним полігоном для вивчення геодинамічних процесів в кристалічній корі, що знаходять своє відображення в сейсмічному режимі, особливо для слабких подій. У доповіді розглянуто установка в Карелії сейсмологічних станцій та результати моніторингу природних та техногенних подій. Досвід останнього десятиріччя показує, що поряд з традиційним завданням вивчення і сейсмічного контролю вибухів в 15 кар'єрах при видобуванні корисних копалин, виникають і частішають випадки, супутні технічній діяльності людини. Це падіння ступенів ракет, пов'язаних з невдалими запусками; аварії на промислових підприємствах і підводних човнах, що супроводжуються вибухами; падіння літаків. Великі обвалення підземних виробок, викликані гірничими роботами; слабкі струси, пов'язані 3 вибухами побутового газу і терористичними актами; знищення боєприпасів з простроченим терміном зберігання - такий неповний список катастроф, пов'язаний з активізацією антропогенних впливів на земну кору. У цю групу відносять морозобійні удари, що виникають як при морозному розтріскуванні грунту (наприклад, при різкій зміні температур), так і при розтріскуванні льоду у водоймах. 
Сейсмический мониторинг природных и техногенных событий на территории Карелии

Н.В. Шаров, (Институт геологии Карельского научного иентра РАН)

\section{РЕЗЮМЕ}

Следует подчеркнуть, что именно Карелия, характеризующаяся незначительным по мощности осадочным чехлом, может стать своеобразным полигоном для изучения геодинамических процессов в кристаллической коре, находящих свое отражение в сейсмическом режиме, особенно для слабых событий. В докладе рассмотрена установка в Карелии сейсмологических станций и результаты мониторинга природных и техногенных событий. Опыт последнего десятилетия показывает, что наряду с традиционной задачей изучения и сейсмического контроля взрывов в 15 карьерах при добыче полезных ископаемых, возникают и учащаются случаи, сопутствующие технической деятельности человека. Это падение ступеней ракет, связанных с неудачными запусками; аварии на промышленных предприятиях и подводных лодках, сопровождающиеся взрывами; падения самолетов. Крупные обрушения подземных выработок, вызванные горными работами; слабые сотрясения, связанные с взрывами бытового газа и террористическими актами; уничтожение боеприпасов с истекшим сроком хранения - таков неполный список катастроф, связанный с активизацией антропогенных воздействий на земную кору. В эту группу относят морозобойные удары, возникающие как при морозном растрескивании грунта (например, при резкой смене температур), так и при растрескивании льда в водоемах. 
В настоящее время вопросы регистрации сейсмических явлений на планете переживают своеобразное «второе дыхание» - наблюдается тенденция к постановке плотных наблюдательных сейсмологических сетей в районах, ранее считавшихся асейсмичными или слабосейсмичными. Этот интерес объясняется двумя причинами: во-первых, изменением представлений о тектонической активности платформ и щитов и, во-вторых, кругом проблем техногенного взаимодействия с литосферой - от наведенной сейсмичности до исследований сейсмического режима в районах размещения крупных промышленных объектов. Сейсмичность северо-запада России хотя и не приводит к катастрофическим последствиям, но при значительной концентрации в этом районе промышленных предприятий, подземных коммуникаций, газопроводов, может вызвать чрезвычайные ситуации, например, прорыв подземных вод, распространение радиоактивных и химических отходов из существующих могильников.

Следует подчеркнуть, что именно Карелия, характеризующаяся незначительным по мощности осадочным чехлом, может стать своеобразным полигоном для изучения геодинамических процессов в кристаллической коре, находящих свое отражение в сейсмическом режиме, особенно для слабых событий. В докладе рассмотрена установка в Карелии сейсмологических станций и результаты мониторинга природных и техногенных событий. Опыт последнего десятилетия показывает, что наряду с традиционной задачей изучения и сейсмического контроля взрывов в 15 карьерах при добыче полезных ископаемых, возникают и учащаются случаи, сопутствующие технической деятельности человека. Это падение ступеней ракет, связанных с неудачными запусками; аварии на промышленных предприятиях и подводных лодках, сопровождающиеся взрывами; падения самолетов. Крупные обрушения подземных выработок, вызванные горными работами; слабые сотрясения, связанные с взрывами бытового газа и террористическими актами; уничтожение боеприпасов с истекшим сроком хранения - таков неполный список катастроф, связанный с активизацией антропогенных воздействий на земную кору. В эту группу относят морозобойные удары, возникающие как при морозном растрескивании грунта (например, при резкой смене температур), так и при растрескивании льда в водоемах.

Таким образом, перед нами открываются огромные возможности по мониторингу, прогнозированию и оценке различных внешних воздействий. В современном мире, когда человек уязвим перед природными и техногенными катастрофами, открывающиеся возможности помогут нам подготовиться к таким угрозам. 